\title{
A RECLAMAÇÃO COMO INSTRUMENTO DE UNIDADE NO DIREITO BRASILEIRO ${ }^{1}$
}

\section{THE CONSTITUCIONAL COMPLAINT AS AN INSTRUMENT OF UNITY IN BRAZILIAN'S LAW}

Thiago Simões Pessoa Mestrando em direitos fundamentais e democracia. Pós Graduado em Direito Processual Civil pelo Instituto Romeu Felipe Bacellar. Pós graduado em Direito Tributário pela Pontifícia Universidade Católica de Minas Gerais. Graduado pela Universidade Católica Dom Bosco. Procurador do Estado do Paraná. Curitiba/PR. E-mail: thiago-simpes@hotmail.com

William Soares Pugliese Pós-doutorando pela UFRGS. Professor do Programa de Mestrado do Centro Universitário Autônomo do Brasil (Unibrasil). Mestre e Doutor em Direito pelo PPGD-UFPR. Gastforscher no Max-Planck-Institut für ausländisches öffentliches Recht und Völkerrecht. Coordenador da Especialização de Direito Processual Civil da Academia Brasileira de Direito Constitucional (ABDConst). Membro da Comissão de Estudos Constitucionais da Ordem dos Advogados do Brasil, Seção Paraná (OAB/PR). Advogado. Curitiba/PR. E-mail: william@1xp.adv.br

RESUMO: Trata-se o presente texto sobre uma proposta de racionalização do sistema recursal brasileiro, alinhando-se os precedentes vinculantes ao cabimento da reclamação constitucional. Nesta linha, será realizada uma análise desde a formação de decisões judiciais,

\footnotetext{
${ }^{1}$ Artigo recebido em 17/01/2019 e aprovado em 29/07/2019.
} 
à luz da integridade, até a formação dos precedentes e sua consequente aplicação e vinculatividade às demais instâncias ordinárias.

PALAVRAS-CHAVE: Integridade; Precedente; Efeito Vinculante; Julgamento de recursos repetitivos; Reclamação.

\begin{abstract}
This text is about a proposal to rationalize the Brazilian appellate system, aligning the binding precedents to the compliance of the constitutional complaint. In this line, an analysis will be carried out from the formation of judicial decisions, in the light of integrity, up to the formation of precedents and their consequent application and binding to other ordinary instances.
\end{abstract}

KEY WORDS: Integrity; Precedent; Binding Effect; Judgement of repetitive appeals; Constitutional Complaint.

\title{
INTRODUÇÃO
}

O Novo Código de Processo Civil entrou em vigor em nosso sistema jurídico em 2016, tendo uma prévia reforma no início do mesmo ano, por meio da Lei 13.256/2016, a qual promoveu algumas alterações no Código, notadamente no campo dos recursos e da reclamação. Apesar das alterações promovidas inicialmente na seara recursal, a teleologia se manteve. Busca o Código promover um sistema mais racional e eficiente, por meio do estabelecimento de precedentes e métodos de julgamento hábeis a conferir maior isonomia e eficiência na prestação jurisdicional.

Deste modo, atualmente, os precedentes são uma realidade no sistema brasileiro, senão já desde antes da vigência do Novo CPC, com o estabelecimento do regime de julgamento de ações de controle de constitucionalidade e recursos repetitivos, agora com expressa menção no Código de sua observância necessária pelos órgãos inferiores (vertical) ou não (horizontal). 
O presente artigo visa primordialmente relacionar o regime de precedentes estabelecido no Código de Processo Civil, notadamente os recursos especiais e extraordinários repetitivos, com o cabimento da reclamação, ação esta que também sofreu alteração com a vigência do Novo Código.

Para tanto será analisado inicialmente a própria formação do precedente, diferenciando-se este das demais decisões judiciais. Ademais, a própria etapa de formação de uma decisão judicial fará parte desta análise, fazendo uma breve excursão nas linhas da integridade promovida por Ronald Dworkin.

É cediço que o tema é de grande controvérsia, tendo em vista que a vigência do Novo Código é assunto recente e longe de encontrar uniformidade na doutrina brasileira. Porém, a formação do precedente vai muito além do direito posto brasileiro, devendo ser estudado questões jurídicas que foram melhor desenvolvidas na doutrina norte americana, face o maior contato destes com o instituto, visto presenciarem um sistema de Common Law, portanto, mais preocupado com os precedentes e a formação das decisões judiciais.

Ao final, será buscada uma proposta de racionalização do sistema recursal brasileiro, por meio do estabelecimento de um regime de admissibilidade recursal mais rigoroso, com base nos recursos repetitivos já decididos, encontrando um respaldo da garantia do sistema no instituto da reclamação.

\section{A FORMAÇÃO DO PRECEDENTE}

\subsection{A integridade de Dworkin e a formação das decisões judiciais}

Inicialmente, pode-se dizer que Dworkin fora um dos autores mais importantes no tocante à interpretação judicial, notadamente na segunda metade do Séc XX, e contribuiu de forma ativa para o desenvolvimento da teoria da decisão judicial.

O autor se apresenta como um grande crítico do positivismo ${ }^{2}$, se destacando como um filósofo da linguagem, admitindo que as normas detém um caráter aberto à interpretação,

\footnotetext{
${ }^{2}$ Ver, nesta linha, MACEDO JR., Ronaldo Porto. Do xadrez à cortesia: Dworkin e a teoria do direito contemporânea. São Paulo: Saraiva, 2013.
} 
Rio de Janeiro. Ano 13. Volume 20. Número 3. Setembro a Dezembro de 2019

Periódico Quadrimestral da Pós-Graduação Stricto Sensu em Direito Processual da UERJ

Patrono: José Carlos Barbosa Moreira (in mem.). ISSN 1982-7636. pp. 575-596

www.redp.uerj.br

o que impossibilita tratar o direito como mera questão de fato, dado também ser necessária a construção da norma pelo processo interpretativo proporcionado pela linguagem e sua estrutura abertura.

Ademais, para Dworkin ${ }^{3}$, não cabe ao julgador o poder discricionário de criar o direito diante do caso concreto, a exemplo do que é sugerido por Herbert Hart ${ }^{4}$ nos casos difíceis, mas sim descobrir o direito, utilizando-se para tanto as normas pré-existentes (regras, princípios e diretrizes políticas), adotando uma teoria da resposta correta, obtida por meio de um processo interpretativo.

Nada obstante, para se obter esta norma, o juiz passará por diversas etapas até o deslinde final da decisão judicial, sendo a integridade a questão chave para se chegar ao resultado almejado.

Difícil se conceituar a integridade para Dworkin, não aparecendo em sua obra nem mesmo um conceito fechado deste instituto. Nada obstante, é possível observar que estaria presente em todos os campos do direito, aparecendo com destaque no campo jurisdicional, que é inclusive o foco de sua obra.

Neste âmbito, o autor começa com uma analogia a um romance em cadeia ${ }^{5}$. Neste romance, cada autor seria responsável por escrever um capítulo após o outro, de modo que devesse manter coerência com a história anteriormente escrita por outro autor, ao tempo que também gozaria de certa liberdade para traçar o futuro da obra.

Com esta analogia, Dworkin quer mostrar que o juiz, ao decidir um caso, deve se ater as razões pretéritas, presentes e futuras, porém, encontrando certa margem de liberdade para traçar a interpretação da norma jurídica, encontrando-se preso ao direito vigente e aos precedentes já existentes. Assim, para o autor, o processo interpretativo da decisão judicial se encontra no meio caminho entre a inexistência de liberdade e a total discricionariedade, notadamente nos casos difíceis.

Portanto, a integridade no campo jurisdicional se liga à ideia de formação da decisão judicial, levando em conta o acervo jurídico pré-existente, no qual se encontram os

\footnotetext{
${ }^{3}$ DWORKIN, Ronald. Levando os direitos a sério. 3 ed. São Paulo: Martins Fontes, 2010. p. 127.

${ }^{4}$ HART, Herbert. O conceito de direito. São Paulo: Martins Fontes, 2009. p. 161-183.

${ }^{5}$ DWORKIN, Ronald. O império do Direito. São Paulo: Martins Fontes, 1999. p. 275-286.
} 
precedentes judiciais, o direito posto, incluindo as regras, os princípios e as diretrizes políticas.

\subsection{As qualidades de um precedente segundo Melvin Eisenberg}

Como já analisado no tópico anterior, à luz das lições de Dworkin, observa-se que a formação da decisão judicial é algo além da simples discricionariedade ou do direito legislado, mas sim se liga ao respeito do direito pré-existente, onde também se incluem os precedentes judiciais.

Nada obstante, deve ser evidenciado que precedente judicial não se confunde com decisão judicial. Segundo a doutrina ${ }^{6}$, a decisão judicial poderia ser vista como uma declaração judicial que estabelece de alguma forma uma consequência jurídica, enquanto precedente seria "uma decisão anterior que serve como modelo para decisões posteriores"7, ou seja, seriam razões generalizáveis, extraídas de uma decisão judicial qualificada.

Deste modo, o precedente seria uma decisão judicial qualificada, devendo ser elaborada de uma forma diferenciada das demais decisões judiciais, tendo em vista a possibilidade de replicação para casos futuros.

Assim, ao proferir esta decisão, devem as Cortes de Precedentes, além de levar em conta todo o acervo jurídico já existente, como já demonstrado pela ideia de Dworkin na formação da decisão judicial, utilizar outros parâmetros, em razão de sua qualidade especial, sendo as ideias de Melvin Eisenberg ${ }^{8}$ adequadas para esta análise.

Segundo o autor, ao formar precedentes (decisões judiciais qualificadas) a Corte deve se atentar para alguns padrões, como a objectivity ${ }^{9}$, que se relaciona à questão da imparcialidade - juiz não pode se encontrar vinculado às partes - e da universalidade decisão deve ser apta a ser aplicada de maneira geral àqueles que não sejam partes. Ademais,

\footnotetext{
${ }^{6}$ PUGLIESE, William Pugliese. Princípios da Jurisprudência. Belo Horizonte: Arraes, 2017. p. 22. ${ }^{7}$ PUGLIESE, William Pugliese. Princípios da Jurisprudência. Belo Horizonte: Arraes, 2017. p. 23. ${ }^{8}$ EISENBERG, Melvin Aron. The Nature of the Common Law. Cambridge: Harvard University Press, 1998. p. 8-13.

${ }^{9}$ EISENBERG, Melvin Aron. The Nature of the Common Law. Cambridge: Harvard University Press, 1998. p. 8.
} 
Rio de Janeiro. Ano 13. Volume 20. Número 3. Setembro a Dezembro de 2019

Periódico Quadrimestral da Pós-Graduação Stricto Sensu em Direito Processual da UERJ

Patrono: José Carlos Barbosa Moreira (in mem.). ISSN 1982-7636. pp. 575-596

www.redp.uerj.br

esta decisão deve encontrar suporte em padrões gerais estabelecidos pelo sistema jurídico e pela sociedade ${ }^{10}$.

Ainda deve a Corte se atentar para a replicabilidade ${ }^{11}$, que consiste na possibilidade da decisão poder ser prevista e replicada, bem como indicar o futuro (para decisões de outros casos) para as pessoas relacionadas à área jurídica.

Por fim, existe a questão da responsiveness ${ }^{12}$ ou capacidade de resposta, pela qual também a Corte deve se encontrar aberta às partes e ao público de modo geral a fím de verificar a correção de sua decisão, e também modificá-la no futuro caso necessário.

Ressalte-se que também especialistas e amici curiae devem ter a possibilidade de participarem do debate na formação do precedente, evitando uma decisão indesejada e capaz de trazer maiores prejuízos que benefícios ao ordenamento jurídico vigente.

Por fim, registre-se que o precedente deve se manter estável no decorrer do tempo ${ }^{13}$, tendo as Cortes de Justiça e juízes de primeiro grau a obrigação de segui-lo, não podendo em qualquer hipótese negar sua aplicação, sendo este efeito vinculante a razão principal desta decisão qualificada ser proferida com base em todos parâmetros trazidos acima, a fim de conferir maior legitimidade e segurança ao precedente.

\subsection{Os precedentes vinculantes no NCPC}

O Novo Código de Processo Civil estabeleceu, em seu art. 927, algumas espécies de decisões judiciais que deveriam ser objeto de observância pelos demais julgadores. Dentre eles se encontram alguns precedentes. Neste ponto, serão analisados alguns destes, utilizando como critério de qualificação do precedente o cabimento ou não de reclamação, utilizando-se a classificação de Patrícia Perrone Campos Mello, promovida em seu artigo, $O$

\footnotetext{
${ }^{10}$ EISENBERG, Melvin Aron. The Nature of the Common Law. Cambridge: Harvard University Press, 1998. p. 9.

${ }^{11}$ EISENBERG, Melvin Aron. The Nature of the Common Law. Cambridge: Harvard University Press, 1998. p. 10.

${ }^{12}$ EISENBERG, Melvin Aron. The Nature of the Common Law. Cambridge: Harvard University Press, 1998. p. 12.

${ }^{13}$ EISENBERG, Melvin Aron. The Nature of the Common Law. Cambridge: Harvard University Press, 1998. p. 45 .
} 
Rio de Janeiro. Ano 13. Volume 20. Número 3. Setembro a Dezembro de 2019

Periódico Quadrimestral da Pós-Graduação Stricto Sensu em Direito Processual da UERJ

Patrono: José Carlos Barbosa Moreira (in mem.). ISSN 1982-7636. pp. 575-596

www.redp.uerj.br

Supremo e os precedentes constitucionais: como fica a sua eficácia após o Novo Código de Processo Civil.

Neste texto, a autora traz três espécies de eficácia dos precedentes, sendo elas: a eficácia normativa, a eficácia persuasiva e a intermediária ${ }^{14}$. A eficácia normativa, identificada no texto com a eficácia vinculante, seria aqueles precedentes que dão ensejo ao cabimento de reclamação.

De outro lado, os precedentes com eficácia persuasiva seriam aqueles que não obrigariam os órgãos inferiores, prestando-se a apoiar argumentativamente os pedidos das partes e provimentos jurisdicionais emanados do judiciário.

Por fim, o precedente com eficácia intermediária se "caracteriza por uma decisão ou por um conjunto de decisões que produzem efeitos para além do caso julgado, ainda que não tenham que ser obrigatoriamente seguidos pelos demais órgãos judiciais ou ainda que as decisões delas divergentes não ensejem a propositura de reclamação." ${ }^{15}$.

Em sentido semelhante, Eduardo Talamini e Luiz Rodrigues Wambier ${ }^{16}$ dividem a eficácia dos precedentes em eficácia fraca - aquela que indica somente uma eficácia persuasiva; eficácia média, na qual a lei autoriza providências judiciais e administrativas para abreviar o processo e o procedimento; e a eficácia forte, considerada aquela que vincula as demais autoridades ao decidido, possibilitando inclusive o cabimento de reclamação para garantir a autoridade do precedente.

Para fins do presente artigo, será adotada a teoria que identifica os precedentes vinculantes ou normativos com a consequência de cabimento de reclamação para garantir a autoridade daqueles.

O Código de Processo Civil, em seu art. 988, prevê os casos que poderão ser objeto de reclamação, dentre eles se encontram como novidade o cabimento desta importante ação para garantir a observância de decisões proferidas em sede de IRDR, assunção de competência e julgamento de recursos repetitivos.

\footnotetext{
${ }^{14}$ MELLO, Patrícia Perrone Campos. O Supremo e os precedentes constitucionais: como fica a eficácia após o Novo Código de Processo Civil. Universitas Jus. Brasília, v. 26, n. 2, p. 42-43, 2015.

${ }^{15}$ MELLO, Patrícia Perrone Campos. O Supremo e os precedentes constitucionais: como fica a eficácia após o Novo Código de Processo Civil. Universitas Jus. Brasília, v. 26, n. 2, p. 43, 2015.

${ }^{16}$ TALAMINI, Eduardo. WAMBIER, Luiz Rodrigues. Curso Avançado de Processo Civil. 16. ed. v.2. São Paulo: Revista dos Tribunais, 2016. p. 696-698.
} 
Rio de Janeiro. Ano 13. Volume 20. Número 3. Setembro a Dezembro de 2019

Periódico Quadrimestral da Pós-Graduação Stricto Sensu em Direito Processual da UERJ

Patrono: José Carlos Barbosa Moreira (in mem.). ISSN 1982-7636. pp. 575-596

www.redp.uerj.br

Registre-se que há fundada controvérsia acerca da natureza de precedentes de todas estas decisões indicadas, havendo autores ${ }^{17}$ que preferem somente considerar precedentes aqueles proferidos pelas Cortes Superiores (Cortes de Precedentes), cabendo as Cortes de Justiça apenas o proferimento de jurisprudência uniformizadora.Assim, o presente trabalho não descarta a presente interpretação, afastando-se da discussão, mantendo-se somente no caminho dos precedentes emanados dos julgamentos de recursos repetitivos.

\section{OS RECURSOS EXTRAORDINÁRIOS E AS CORTES DE PRECEDENTES}

\subsection{Uma teoria sobre o papel das Cortes Superiores}

A afirmação de que o país precisa conferir eficiência ao direito tem sido reiterada com uma frequência ímpar, uma vez que as Cortes brasileiras julgam excessivamente, não se comparando a qualquer outro lugar do mundo.

Segundo Relatório de Atividades elaborado pelo $\mathrm{STF}^{18}$, no ano de 2017 foram autuados 103.650 novos processos, havendo um acervo final em dezembro do mesmo ano de 45.437 processos. Registre-se que somente quanto a recursos extraordinários e suas decorrências, como agravo interno e agravo em recurso extraordinário, se somaram um total de 85.018 processos recursais, sendo que em 2016 o total era de 77.418 processos recursais, havendo, portanto, um aumento de recursos de um ano para o outro.

Cabe esclarecer que a situação é ainda mais grave quando se considera o Superior Tribunal de Justiça ${ }^{19}$, que no ano de 2017, recebeu o total de 332.284 novos processos, dentre competência recursal e originária. Deste total, 179.698 são Agravos em Recursos Especiais,

\footnotetext{
${ }^{17}$ MITIDIERO, Daniel. Precedentes: da persuasão à vinculação. 3 ed. São Paulo: Revista dos Tribunais, 2018. p. 74-79.

${ }^{18}$ Relatório de atividades 2017 [recurso eletrônico]: Supremo Tribunal Federal/ Supremo Tribunal Federal. Brasília: STF, Secretaria de Documentação, 2018. p. 32. Disponível em $<$ http://www.stf.jus.br/arquivo/cms/centralDoCidadaoAcessoInformacaoGestaoEstrategica/anexo/RelatorioA tividadesSTF2017.pdf $>$. Acesso em 09 de julho de 2018.

${ }^{19}$ Relatório Estatístico do STJ no exercício de 2017. Documento eletrônico. p. 15-19. Disponível em

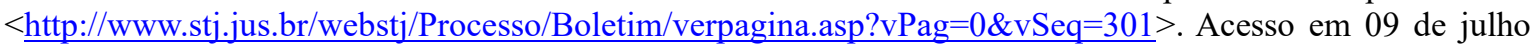
de 2018
} 
Rio de Janeiro. Ano 13. Volume 20. Número 3. Setembro a Dezembro de 2019

Periódico Quadrimestral da Pós-Graduação Stricto Sensu em Direito Processual da UERJ

Patrono: José Carlos Barbosa Moreira (in mem.). ISSN 1982-7636. pp. 575-596

www.redp.uerj.br

sendo ainda 68.143 Recursos Especiais, o que demonstra a alta taxa de subida dos recursos extraordinários às Cortes Superiores.

A fim de realizar uma breve comparação com a Corte Norte Americana, segundo informações obtidas em consulta ao site da entidade ${ }^{20}$, vislumbra-se que todo ano em média 7 a 8 mil novos casos são distribuídos à Corte, sendo este um número considerado extremamente elevado pelo país, sendo o maior desde o seu início. Registre-se ainda que, em razão de uma sistemática de racionalização dos julgamentos, a Corte dos EUA realiza o julgamento de cerca de 200 processos anuais, sendo em média 80 com sustentação oral em plenário e outros 100 , em média, sem a necessidade deste procedimento mais complexo.

Deste modo, é fácil visualizar que o sistema atual adotado pelas Cortes Superiores não é suficiente para conferir racionalização ao Direito, bem como vai de encontro ao princípio da eficiência, tão bem defendido e presente inclusive em nossa Carta Constitucional.

Assim, é necessário se propor um novo sistema, onde caiba às Cortes Superiores apenas o papel de produzir precedentes, remanescendo às instâncias inferiores o papel de julgar o direito do caso concreto, bem como uniformizar a jurisprudência local, papel este desempenhado notadamente pelas Cortes de Justiça. É nesta linha que se apresenta a teoria de Daniel Mitidiero, adotada neste trabalho como marco teórico.

Segundo o autor, "é preciso distinguir entre as funções das Cortes de JustiçaTribunais de Justiça e Tribunais Regionais Federais - e as funções das Cortes de Precedentes - que ocupam o 'vértice' da organização judiciária, Supremo Tribunal Federal e Superior Tribunal de Justiça. Em outras palavras, importa perceber a necessidade de reconstrução do sistema judiciário" ${ }^{21}$.

Permeando a proposta do autor ${ }^{22}$, podemos observar que caberia às Cortes de Justiça o papel de realizar o segundo grau de jurisdição, responsável por funcionar como um controle das causas já decididas em primeira instância, bem como ainda uniformizar a

\footnotetext{
${ }^{20}$ Supreme Court Of United States. Disponível em $<\underline{\text { https: } / / w w w . s u p r e m e c o u r t . g o v / a b o u t / c o u r t a t w o r k . a s p x ~}>$. Acesso em 10 de julho de 2018.

${ }^{21}$ MITIDIERO, Daniel. Precedentes: da persuasão à vinculação. 3 ed. São Paulo: Revista dos Tribunais, 2018. p. $80-81$.

${ }^{22}$ MITIDIERO, Daniel. Precedentes: da persuasão à vinculação. 3 ed. São Paulo: Revista dos Tribunais, 2018. p. 81 .
} 
jurisprudência no âmbito da competência do Tribunal, o que se daria por meio dos julgamentos em IRDR e assunção de competência, sem prejuízo de outras ações e competências recursais.

De outro lado, às Cortes de Precedentes caberia o único papel de conferir unidade ao direito por meio da outorga da última palavra acerca do tema objeto de recurso, formando um precedente, observando rito específico - como mencionado nos itens 1.1 e 1.2 deste trabalho, que deveria ser objeto de replicação e observância pelas Cortes de Justiça e demais juízes de primeira instância.

Esta proposta é suficiente - senão necessária - para conferir eficiência ao sistema jurídico recursal, não podendo se aceitar em épocas de precedentes vinculantes que uma Corte de Precedentes julgue mais de 100 mil processos em um ano, o que demonstra a irrazoabilidade do sistema atual.

Ademais, é possível observar que este sistema encontra guarida no Novo Código de Processo Civil, tendo em vista que se infere do regime de recursos repetitivos (e da antiga repercussão geral) uma abertura para que as Cortes Superiores se caracterizem unicamente como Cortes de Precedentes.

Insta frisar que, como será enfrentado em tópico posterior, o sistema atual permite a inadmissibilidade de recursos especiais e extraordinários após o julgamento de recursos repetitivos, bem como traz o instituto da reclamação para fazer valer a força destes importantes precedentes.

Advirta-se, por fim, que o presente trabalho adota teoria distinta da de Mitidiero para refletir a respeito da vinculação, conforme já fora exposto no item 1.3 deste trabalho. Nada obstante, quanto à estruturação das Cortes, com base no vigente código, não se pode afastar a importância da teoria do autor supramencionado, o qual contribui de forma significativa para a reestruturação do sistema recursal brasileiro.

\subsection{Os recursos especiais e extraordinários repetitivos no NCPC}


Rio de Janeiro. Ano 13. Volume 20. Número 3. Setembro a Dezembro de 2019

Periódico Quadrimestral da Pós-Graduação Stricto Sensu em Direito Processual da UERJ

Patrono: José Carlos Barbosa Moreira (in mem.). ISSN 1982-7636. pp. 575-596

www.redp.uerj.br

Os recursos especiais e extraordinários repetitivos não são novidade no Código de Processo Civil. Este regime de julgamento fora estabelecido já na vigência do Código de 1973, constando de seus antigos artigos 543-B seguintes.

Registre-se que no antigo Código somente havia menção a expressão "recursos repetitivos" no tocante ao Recurso Especial, havendo certa confusão quanto ao Recurso Extraordinário referente a utilização da repercussão geral, a qual poderia dar origem a casos repetitivos ou não.

Nada obstante, na vigência do Novo Código a imprecisão terminológica fora resolvida, passando-se a utilizar a expressão "recursos repetitivos" tanto para os Recursos Especiais como para os Recursos Extraordinários.

Por meio deste sistema, que consta dos art. 1.036 e seguintes do Novo Código, caberá a afetação dos recursos extraordinários e especiais sempre que houver multiplicidade de recursos, com idêntica questão de direito, tornando racional o julgamento da matéria, a qual será julgada de forma uniforme em uma única decisão que será replicada aos demais casos em razão de se tratar de um precedente vinculante, nos termos do art. 927, III, do NCPC.

Assim, as Cortes Superiores, que antes já promoviam o julgamento de recursos repetitivos, passaram, com a edição do NCPC, de meras prolatoras de precedentes com eficácia persuasiva, para verdadeiras Cortes de Precedentes, tendo em vista que seus julgamentos, ao menos no tocante ao caso dos recursos repetitivos, é atribuída força vinculante.

Com isso, verifica-se que a tese de Daniel Mitidiero, exposta em tópico anterior, encontra respaldo na realidade atual do Código de Processo, podendo ser aceita a interpretação no sentido de tornar as Cortes Superiores em verdadeiras Cortes de Precedentes.

2.3 Os recursos repetitivos como requisito de admissibilidade recursal (art. 1.042, do CPC)

Como já exposto no tópico anterior, o Código de Processo manteve o instituto dos recursos repetitivos e ainda ampliou sua qualidade, alterando seu status de precedente com 
Rio de Janeiro. Ano 13. Volume 20. Número 3. Setembro a Dezembro de 2019

Periódico Quadrimestral da Pós-Graduação Stricto Sensu em Direito Processual da UERJ

Patrono: José Carlos Barbosa Moreira (in mem.). ISSN 1982-7636. pp. 575-596

www.redp.uerj.br

eficácia meramente persuasiva para eficácia vinculante, com base no cabimento da reclamação.

Porém, este fator não é a única novidade do Código de Processo atual. Hoje, podemos verificar que o código ainda buscou ir além. Se não bastasse ter tornado estes precedentes em vinculantes, o Código também parece ter vedado o cabimento de novos recursos especiais e extraordinários após o julgamento de um recurso repetitivo.

Inicialmente, em seu art. 1.030, I, do Código de Processo, este é expresso que cabe ao Presidente ou ao Vice Presidente do Tribunal, negar seguimento a REsp ou RE que veicule: a) tese a que o STF tenha negado a existência de repercussão geral; b) tese que se encontre em consonância com recurso repetitivo já julgado pelas Cortes Superiores.

Ademais, o art. 1.042, do NCPC, passou a prever que cabe agravo às Cortes Superiores "contra decisão do presidente ou do vice-presidente do tribunal recorrido que inadmitir recurso extraordinário ou recurso especial, salvo quando fundada na aplicação de entendimento firmado em regime de repercussão geral ou em julgamento de recursos repetitivos".

Deste modo, vislumbra-se que a lei expressamente veda o cabimento de agravo do art. 1.042 nos casos em que a decisão do Tribunal local estiver fundada em precedente firmado em sede de repercussão geral ou em julgamento de recursos repetitivos, casos para os quais somente será cabível o recurso de agravo interno, nos moldes do art. 1.030, $\S 2^{\circ}$, do NCPC.

Para esclarecer a matéria, cabe trazer as lições da doutrina ${ }^{23}$ :

Refere o legislador ainda que da decisão de inadmissibilidade fundada no inciso $\mathrm{V}$ do art. 1.030 caberá, conforme o caso, agravo em recurso extraordinário ou em recurso especial (art. 1.042). Da decisão proferida com fundamento nos incisos I e III caberá agravo interno (art. 1.021). O órgão colegiado que tem o dever de conhecer o recurso de agravo interno é o plenário ou a corte especial do tribunal de origem.

Como se vê, com a nova redação do art. 1.030, CPC, o juízo de admissibilidade do recurso extraordinário e do recurso especial permanece sendo em um primeiro momento tarefa do presidente ou do vice-presidente do tribunal de origem. Negada admissibilidade, esse juízo sucessivamente é outorgado ao colegiado do tribunal recorrido (agravo interno) e à

\footnotetext{
${ }^{23}$ MARINONI, Luiz Guilherme; ARENHART, Sérgio Cruz; MITIDIERO, Daniel. Curso de Processo Civil.
} 3. Ed. v.2. São Paulo: Revista dos Tribunais, 2017. p. 560. 
Rio de Janeiro. Ano 13. Volume 20. Número 3. Setembro a Dezembro de 2019

Periódico Quadrimestral da Pós-Graduação Stricto Sensu em Direito Processual da UERJ

Patrono: José Carlos Barbosa Moreira (in mem.). ISSN 1982-7636. pp. 575-596

www.redp.uerj.br

instância extraordinária competente (agravo em recurso extraordinário ou em recurso especial para o STF ou STJ). O juízo positivo de admissibilidade não desafia recurso.

A contrario sensu, é possível observar que a inexistência de precedente formado em julgamento de recursos especiais e extraordinários repetitivos se tornou um requisito negativo de admissibilidade recursal, dado que, havendo um precedente neste sentido, caberá a Corte Justiça somente aplicá-lo, não sendo sequer possível o cabimento de agravo ao STJ e ao STF para modificar o entendimento da Corte subordinada.

Assim, pode-se afirmar que, nestes casos, "Como se vê, o acórdão do julgamento do Recurso Extraordinário ou do Recurso Especial, no caso de idêntica controvérsia, servirá de base para o juízo de admissibilidade de outros recursos que versem sobre a mesma questão e até para o julgamento de outros recursos ou causas cujos trâmites foram suspensos." 24 .

Insta registrar que o código previu o cabimento do agravo interno para evitar que o precedente seja aplicado indevidamente. Assim, nos casos em que o Presidente, ou o Vice, fizer incidir precedente de forma indevida para barrar o recurso especial ou extraordinário, ou mesmo deixar de aplicar precedente vigente, caberá ao recorrente lançar mão do recurso de agravo interno e eventualmente, no caso de permanência do equívoco, da reclamação constitucional $^{25}$.

Ressalte-se que somente será cabível eventual reclamação após o julgamento do agravo interno, quando esgotadas as instâncias ordinárias, para garantir ou fazer incidir precedente vinculante formado em sede de julgamento de recursos repetitivos, nos moldes do que consta expressamente do art. $988, \S 5^{\circ}$, II, do NCPC.

\section{A RECLAMAÇÃO COMO INSTRUMENTO DE UNIDADE NO DIREITO}

\subsection{A reclamação como garantidora dos Precedentes vinculantes}

\footnotetext{
24 DONIZETTI, Elpidio. A força dos precedentes no Novo Código de Processo Civil. Revista Direito UNIFACS. Salvador, n. 175. p. 25. 2015.

${ }^{25}$ PESSOA, Thiago Simões. Das modificações operadas após a publicação do Novo Código de Processo Civil Brasileiro de 2015. SANTANA, Alexandre Ávalo; ANDRADE NETO, José de (Coords.) Novo CPC: Análise Doutrinária sobre o novo direito processual brasileiro. 2 ed. V. 1. Campo Grande: Contemplar, 2019. p. 700.
} 
A reclamação, apesar de entendimentos divergentes no âmbito das Cortes Superiores, é tida pela doutrina ${ }^{26}$ como ação autônoma de impugnação de natureza constitucional, a qual visa garantir a preservação da competência das Cortes ou a autoridade de suas decisões.

Na vigência do CPC-1973, esta ação não fora objeto de tratamento individualizado, tendo o código deixado de prevê-la. Ressalte-se que não havia dificuldade em sua aceitação, uma vez que já havia previsão constitucional expressa da sua existência, evitando qualquer discussão neste sentido.

$\mathrm{Na}$ redação original do CPC-2015, a presente ação fora em muito privilegiada, tendo sido resguardado um capítulo específico do código para sua regulamentação.

E não é só, o instituto ganhou novos patamares, sendo importante na garantia da força cogente dos precedentes vinculantes, dado que previsto seu cabimento, na redação original do código sem qualquer limitação, para garantir a observância de decisão do STF em sede de controle concentrado de constitucionalidade, enunciados de súmula vinculante, de precedentes proferidos em julgamento de casos repetitivos (recursos repetitivos e IRDR) e de incidente de assunção de competência.

No entanto, com a edição da Lei 13.256/2015, fora dada nova redação aos incisos III e IV do art. 988, do Código, bem como se estabeleceu uma limitação temporal para o cabimento de reclamação em face de julgamentos proferidos em desacordo com precedentes oriundos de recursos repetitivos.

Com a edição da lei, passou a ser cabível a reclamação, além dos casos clássicos já previstos constitucionalmente, para garantir a observância de súmula vinculante e de decisão do STF em sede de controle concentrado, bem como para garantir a observância de acórdão proferido em julgamento de incidente de resolução de demandas repetitivas ou em incidente de assunção de competência.

Deste modo, observa-se uma mudança sutil na redação do dispositivo legal, o qual retirou o cabimento de reclamação nos casos de recursos repetitivos, fazendo não mais

\footnotetext{
${ }^{26}$ DIDIER, JR. Fredie. CUNHA, Leonardo Carneiro. Curso de Direito Processual Civil. ed. 13. V. 3. Salvador: Juspodivm, 2016. p. 533.
} 
menção ao gênero "casos repetitivos", mas especificando uma de suas espécies, qual seja o incidente de resolução de demandas repetitivas (IRDR).

Nada obstante, a alteração legislativa não suprimiu de vez o cabimento da reclamação nos casos de julgamento de recursos repetitivos, tendo sido inserido o inciso II, no bojo do parágrafo $5^{\circ}$, do art. 988, o qual afirma que não será cabível reclamação "proposta para garantir a observância de acórdão de recurso extraordinário com repercussão geral reconhecida ou de acórdão proferido em julgamento de recursos extraordinário ou especial repetitivos, quando não esgotadas as instâncias ordinárias".

Assim, a contrario sensu, é plenamente cabível a reclamação em face de julgamentos em desacordo com precedentes formados em recursos repetitivos, desde que respeitada a limitação temporal, qual seja o esgotamento das instâncias ordinárias.

Ressalte-se que tal alteração veio contemplar a ideia de vedação de cabimento de novos recursos especiais e extraordinários após o julgamento de recursos repetitivos, dado que não é crível se pensar que, ao invés de racionalizar o sistema, o legislador criou mais uma ação para conviver com os recursos extraordinários nestes casos.

\subsection{Os recursos repetitivos e o cabimento de reclamação}

Os recursos repetitivos, como já se teve oportunidade de demonstrar supra, passaram de precedentes com mera força persuasiva, para se tornar verdadeiros precedentes vinculantes, hábeis a ensejar o cabimento de reclamação. Nada obstante, após a reforma estabelecida pela Lei 13.256/2016, esta reclamação somente poderá ser objeto de interposição após esgotadas as instâncias ordinárias.

Porém, ao revés do que se pode parecer à primeira vista, não se retirou a força cogente destes precedentes em razão da limitação temporal estabelecida, tendo em vista que, nos casos em que existir recursos repetitivos já julgados, sequer será possível a apresentação de novo Recurso Especial ou Extraordinário, bem como agravo para as Cortes Superiores no caso de sua denegação, conforme já demonstrado da interpretação retirada do art. 1.030, do NCPC. 
Rio de Janeiro. Ano 13. Volume 20. Número 3. Setembro a Dezembro de 2019

Periódico Quadrimestral da Pós-Graduação Stricto Sensu em Direito Processual da UERJ

Patrono: José Carlos Barbosa Moreira (in mem.). ISSN 1982-7636. pp. 575-596

www.redp.uerj.br

Cabe mencionar neste ponto que a força cogente dos precedentes firmados em julgamentos de recursos repetitivos não se atém somente em matéria civil, tendo também o STJ já se pronunciado em julgamento da Reclamação n. 33862/RS (caso relacionado ao Recurso Especial Repetitivo 1.499.050/RJ no tocante à consumação do crime de roubo) que esta ação também deve ser utilizada quando as Cortes de Justiça, em matéria penal, se neguem a aplicar um precedente vinculante.

Assim, a força cogente se mantém incólume, havendo ainda um novo efeito, qual seja o de impedir novos recursos especiais e extraordinários, funcionando a elaboração do precedente vinculante como verdadeiro requisito de admissibilidade recursal para os novos recursos com matéria idêntica.

Vale ressaltar que nem mesmo a necessidade de overruling pode ser encarada como justificativa para a subida do recurso às Cortes Superiores, o que deve ser exercido por meio da reclamação. Neste ponto, vale salientar que o Supremo Tribunal Federal teve a oportunidade recentemente de utilizar a reclamação como instrumento de overruling de precedente firmado em controle concentrado de constitucionalidade.

3. Reclamação como instrumento de (re)interpretação da decisão proferida em controle de constitucionalidade abstrato. Preliminarmente, arguido o prejuízo da reclamação, em virtude do prévio julgamento dos recursos extraordinários 580.963 e 567.985 , o Tribunal, por maioria de votos, conheceu da reclamação. O STF, no exercício da competência geral de fiscalizar a compatibilidade formal e material de qualquer ato normativo com a Constituição, pode declarar a inconstitucionalidade, incidentalmente, de normas tidas como fundamento da decisão ou do ato que é impugnado na reclamação. Isso decorre da própria competência atribuída ao STF para exercer o denominado controle difuso da constitucionalidade das leis e dos atos normativos. A oportunidade de reapreciação das decisões tomadas em sede de controle abstrato de normas tende a surgir com mais naturalidade e de forma mais recorrente no âmbito das reclamações. É no juízo hermenêutico típico da reclamação - no "balançar de olhos" entre objeto e parâmetro da reclamação - que surgirá com maior nitidez a oportunidade para evolução interpretativa no controle de constitucionalidade. Com base na alegação de afronta a determinada decisão do STF, o Tribunal poderá reapreciar e redefinir o conteúdo e o alcance de sua própria decisão. E, inclusive, poderá ir além, superando total ou parcialmente a decisãoparâmetro da reclamação, se entender que, em virtude de evolução 
hermenêutica, tal decisão não se coaduna mais com a interpretação atual da Constituição $0^{27}$.

Insta frisar que este julgamento proferido pela Corte se deu antes mesmo da vigência do NCPC, demonstrando esta que não há qualquer impedimento em se utilizar a reclamação como instrumento de overruling, podendo ser vista esta importante ação constitucional com outros olhos, ganhando uma nova função a fim de desafogar o Poder Judiciário, cooperando com a diminuição de recursos interpostos às Cortes de Precedentes.

Ademais, esta importante ação constitucional também deve ser utilizada para promover o distinguishing nos casos em que houver a aplicação indevida do precedente pela Corte de Justiça a um caso que não se adeque ao contexto fático-jurídico do precedente formado, uma vez que não será possível a subida de novos recursos, evitando-se assim a usurpação de competência pela Corte inferior.

Deste modo, a Corte de Precedentes deve, nestes casos, cuidar apenas de formação, superação e reinterpretação de Precedentes, não podendo mais, com a vigência do Novo Código, se ater a julgamento de casos concretos individuais, ainda que limitada à vedação de reanálise probatória, salvo quanto ao julgamento de recursos repetitivos.

Portanto, deve-se pensar o sistema de uma forma racional, eliminando recursos superpostos desnecessários e protelatórios, atribuindo ao julgamento de recursos repetitivos uma função de pressuposto recursal. Assim, a reclamação adquire um novo papel, qual seja o de promover a vinculatividade dos precedentes e possibilitar sua alteração nos casos de necessidade de sua superação, seja total ou parcial, ou mesmo para destrancar recursos que tiverem precedentes aplicados indevidamente.

\subsection{A unidade como instrumento de integridade no Direito}

Acima fora possível demonstrar que, com a vigência do Novo Código de Processo civil, ao menos os precedentes firmados em sede de julgamento de recursos repetitivos

\footnotetext{
${ }^{27}$ SUPREMO TRIBUNAL FEDERAL. Reclamação n. 4374, Relator(a): Min. GILMAR MENDES, Tribunal Pleno, julgado em 18/04/2013, ACÓRDÃO ELETRÔNICO DJe-173 DIVULG 03-09-2013 PUBLIC 04-092013.
} 
possuem a característica da vinculatividade, havendo inclusive a previsão de reclamação para garantir sua autoridade, de modo a atribuí-los uma vinculatividade forte.

Ademais, viu-se também que as Cortes Superiores devem ser alçadas à altura de verdadeiras Cortes de Precedentes, atuando somente na formação e alteração de precedentes, libertando-se da antiga função de quase terceira instância recursal.

Para isso, a reclamação aparece como instrumento imprescindível, uma vez que se propõe um novo papel a esta importante ação constitucional, qual seja o de promover a vinculatividade de precedentes e sua respectiva alteração, quando não mais serão cabíveis novos recursos superpostos às Cortes de Precedentes.

Assim, a reclamação por esta ótica se apresenta como importante instrumento hábil a conferir unidade ao direito, tendo em vista que promoverá a adequação dos julgamentos inferiores ao decidido pelas Cortes Supremas em caso de sua não aplicação pelos Tribunais e juízes de primeira instância.

Deste modo, o direito poderá ser visto como algo único e uniforme, promovendose os ideais da isonomia e da eficiência por meio de julgamentos imparciais e padrões quando já existente precedentes no tocante à matéria objeto de recurso. Ainda assim, mesmo nos casos de necessidade de alteração dos precedentes já firmados, a reclamação também aparecerá como apta a conferir unidade, tendo em vista poder ser utilizada como o meio suficiente para levar a questão às Cortes Supremas, que poderão debater eventual necessidade de alteração do precedente.

Registre-se ainda que para evitar um novo acúmulo de trabalho nas Cortes Superiores, o que é exatamente o contrário do que se busca com esta proposta, poderão as reclamações interpostas para promover eventual alteração do precedente serem julgadas sob o rito dos recursos repetitivos, promovendo uma maior eficiência no seu julgamento.

Por fim, também é possível conceber a reclamação como técnica para o exercício do distinguishing, especialmente nas hipóteses em que o tribunal aplicar um precedente indevidamente pela inadequação dos fatos materiais e negar conhecimento do recurso especial ou extraordinário. 
Com estas lições, vislumbra-se que a unidade promovida pela reclamação se adequa perfeitamente às ideias de integridade desenvolvida por Dworkin, notadamente em sua analogia, já citada em item 1.1, com a ideia de romance em cadeia.

Não se pode admitir que as Cortes de Justiça e os juízes de primeira instância continuem a ignorar os precedentes vinculantes formados pelas Cortes de Precedentes. Deve-se impor uma limitação lógica na formação de novas decisões judiciais, as quais devem respeitar não só o direito preexistente, mas também o acervo jurídico constituído por precedentes anteriores.

E para tanto a reclamação é importantíssima, bem como a constituição da ideia de não cabimento de novos recursos especiais e extraordinários após o estabelecimento de um precedente vinculante por meio de recursos repetitivos, sob pena de termos um direito incoerente e mais do que isso, sem qualquer integridade, funcionando de uma forma ilógica, violando importantes princípios constitucionais como a eficiência e a isonomia.

\section{CONCLUSÃO}

A massividade das relações jurídicas tornou o judiciário um grande depósito de processos e litígios. A cada dia se multiplica o número de casos que chegam em busca de uma prestação jurisdicional adequada e efetiva.

Nos dias atuais, não é possível negar a importância da racionalização dos julgamentos, bem como da aplicação de princípios fundamentais ao direito como a eficiência e a isonomia, uma vez que não é condizente com um Estado Democrático de Direito que a prestação jurisdicional, em casos idênticos e múltiplos, seja prestada de maneira distinta a cada jurisdicionado, tornando o resultado da prestação em sorte.

Assim, o Novo CPC buscou efetivamente trazer um novo sistema, baseado em precedentes vinculantes, transformando as Cortes Superiores em verdadeiras Cortes de Precedentes, as quais adquirem o papel de conferir unidade ao Direito, para que este possa ser aplicado de forma uniforme e isonômica nas instâncias ordinárias.

Nesta linha, o julgamento de recursos repetitivos aparece com destaque no cenário atual, dando origem a precedentes vinculantes, evitando que novos casos deem origem a 
Rio de Janeiro. Ano 13. Volume 20. Número 3. Setembro a Dezembro de 2019

Periódico Quadrimestral da Pós-Graduação Stricto Sensu em Direito Processual da UERJ

Patrono: José Carlos Barbosa Moreira (in mem.). ISSN 1982-7636. pp. 575-596

www.redp.uerj.br

novos recursos especiais e extraordinários, dado que a simples existência de um precedente vinculante é suficiente para acarretar a inadmissibilidade de novos recursos por falta de pressuposto recursal.

Nada obstante, tal iniciativa necessitava de um fechamento no sistema, uma vez que não é possível também tolher do jurisdicionado a possibilidade de subir às Cortes de Precedentes para ver o precedente por esta aplicado em caso de negação pelas instâncias ordinárias, o que passa a ser possível por meio da nova reclamação.

Outrossim, também deve existir um instrumento para destrancar novos recursos, com base fático-jurídica distinta, aos quais tenha sido aplicado o precedente de forma indevida, podendo a reclamação ser utilizada como forma de promoção do distinguishing, evitando a eventual usurpação de competência das Cortes de Precedentes pelas Cortes inferiores.

Ademais, não se pode esquecer que a reclamação adquire novos patamares, podendo e devendo ser utilizada como instrumento de garantia da vinculatividade dos precedentes, bem como instrumento hábil a proporcionar a alteração dos precedentes em caso de necessidade em razão da alteração de cenário fático ou jurídico no decorrer do tempo.

Assim, se o sistema que se propõe visa dar maior efetividade, por meio da supressão de novos recursos especiais e extraordinários após o estabelecimento de precedentes vinculantes, ainda se deixa uma garantia, qual seja a reclamação, apta a conferir a unidade ao direito quando as demais instâncias ordinárias se negarem a cumprir os precedentes vinculantes ou os fizer incidir de forma indevida a casos não abrangidos por sua vinculatividade.

E mais, a unidade do direito promove não só uma racionalização do sistema, como também se alinha às ideias de integridade defendida por Dworkin, uma vez que o autor já demonstrava anos atrás que não é possível a prolação de decisões em desacordo com o acervo jurídico pré-existente. Deve-se, portanto, cada novo julgador proferir sua decisão em compasso com os precedentes já existentes, a exemplo de um romancista em cadeia ao continuar uma história por outro iniciada, que deve manter a coerência com certa margem de liberdade para conferir o deslinde da história. 


\section{REFERÊNCIAS}

BRASIL. SUPREMO TRIBUNAL FEDERAL. Reclamação n. 4374, Relator(a): Min. GILMAR MENDES, Tribunal Pleno, julgado em 18/04/2013, ACÓRDÃO ELETRÔNICO DJe-173 DIVULG 03-09-2013 PUBLIC 04-09-2013.

DIDIER, JR. Fredie. CUNHA, Leonardo Carneiro. Curso de Direito Processual Civil. ed. 13. Salvador: Juspodivm, 2016.

DONIZETTI, Elpidio. A força dos precedentes no Novo Código de Processo Civil. Revista Direito UNIFACS. Salvador, n. 175. 1-30. 2015.

DWORKIN, Ronald. Levando os direitos a sério. 3 ed. São Paulo: Martins Fontes, 2010.

DWORKIN, Ronald. O império do Direito. São Paulo: Martins Fontes, 1999.

EISENBERG, Melvin Aron. The Nature of the Common Law. Cambridge: Harvard University Press, 1998.

HART, Herbert. O conceito de direito. São Paulo: Martins Fontes, 2009.

MACEDO JR., Ronaldo Porto. Do xadrez à cortesia: Dworkin e a teoria do direito contemporânea. São Paulo: Saraiva, 2013.

MARINONI, Luiz Guilherme; ARENHART, Sérgio Cruz; MITIDIERO, Daniel. Curso de Processo Civil. 3. Ed. v.2. São Paulo: Revista dos Tribunais, 2017.

MELLO, Patrícia Perrone Campos. O Supremo e os precedentes constitucionais: como fica a eficácia após o Novo Código de Processo Civil. Universitas Jus. Brasília, v. 26, n. 2 , p. 42-53, 2015.

MITIDIERO, Daniel. Precedentes: da persuasão à vinculação. 3 ed. São Paulo: Revista dos Tribunais, 2018.

PUGLIESE, William Pugliese. Princípios da Jurisprudência. Belo Horizonte: Arraes, 2017. Relatório de atividades 2017 [recurso eletrônico]: Supremo Tribunal Federal/ Supremo Tribunal Federal. - Brasília: STF, Secretaria de Documentação, 2018. p. 32. Disponível em

$<\underline{\text { http://www.stf.jus.br/arquivo/cms/centralDoCidadaoAcessoInformacaoGestaoEstrat }}$ egica/anexo/RelatorioAtividadesSTF2017.pdf> . Acesso em 09 de julho de 2018.

Relatório Estatístico do STJ no exercício de 2017. Documento eletrônico.. Disponível em 
Rio de Janeiro. Ano 13. Volume 20. Número 3. Setembro a Dezembro de 2019

Periódico Quadrimestral da Pós-Graduação Stricto Sensu em Direito Processual da UERJ

Patrono: José Carlos Barbosa Moreira (in mem.). ISSN 1982-7636. pp. 575-596

www.redp.uerj.br

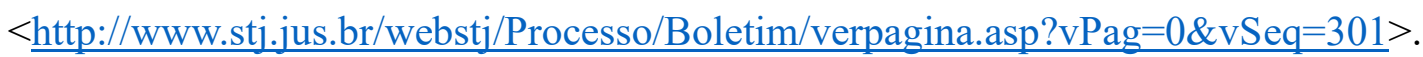

Acesso em 09 de julho de 2018.

TALAMINI, Eduardo. WAMBIER, Luiz Rodrigues. Curso Avançado de Processo Civil. 16. ed. v.2. São Paulo: Revista dos Tribunais, 2016.

PESSOA, Thiago Simões. Das modificações operadas após a publicação do Novo Código de Processo Civil Brasileiro de 2015. SANTANA, Alexandre Ávalo; ANDRADE NETO, José de (Coords.) Novo CPC: Análise Doutrinária sobre o novo direito processual brasileiro. 2 ed. V. 1. Campo Grande: Contemplar, 2019. p. 693-709. 